\title{
Kebertahanan Janda Kristen Batak Toba dalam Hidup Menjanda Setelah Cerai Mati dan Cerai Hidup
}

\author{
Hadriana Marhaeni Munthe1, Harmona Daulay², Napsiah ${ }^{3}$ \\ 1, 2 Fakultas Ilmu Sosial dan Politik, Universitas Sumatera Utara \\ ${ }^{3}$ FakultasIlmu Sosial dan Humaniora, UIN Sunan Kalijaga, Yogyakarta \\ 1hadriana@usu.ac.id, 2harmonadaulay@usu.ac.id, ${ }^{3 n a p s i a h @ u i n-s u k a . a c . i d ~}$
}

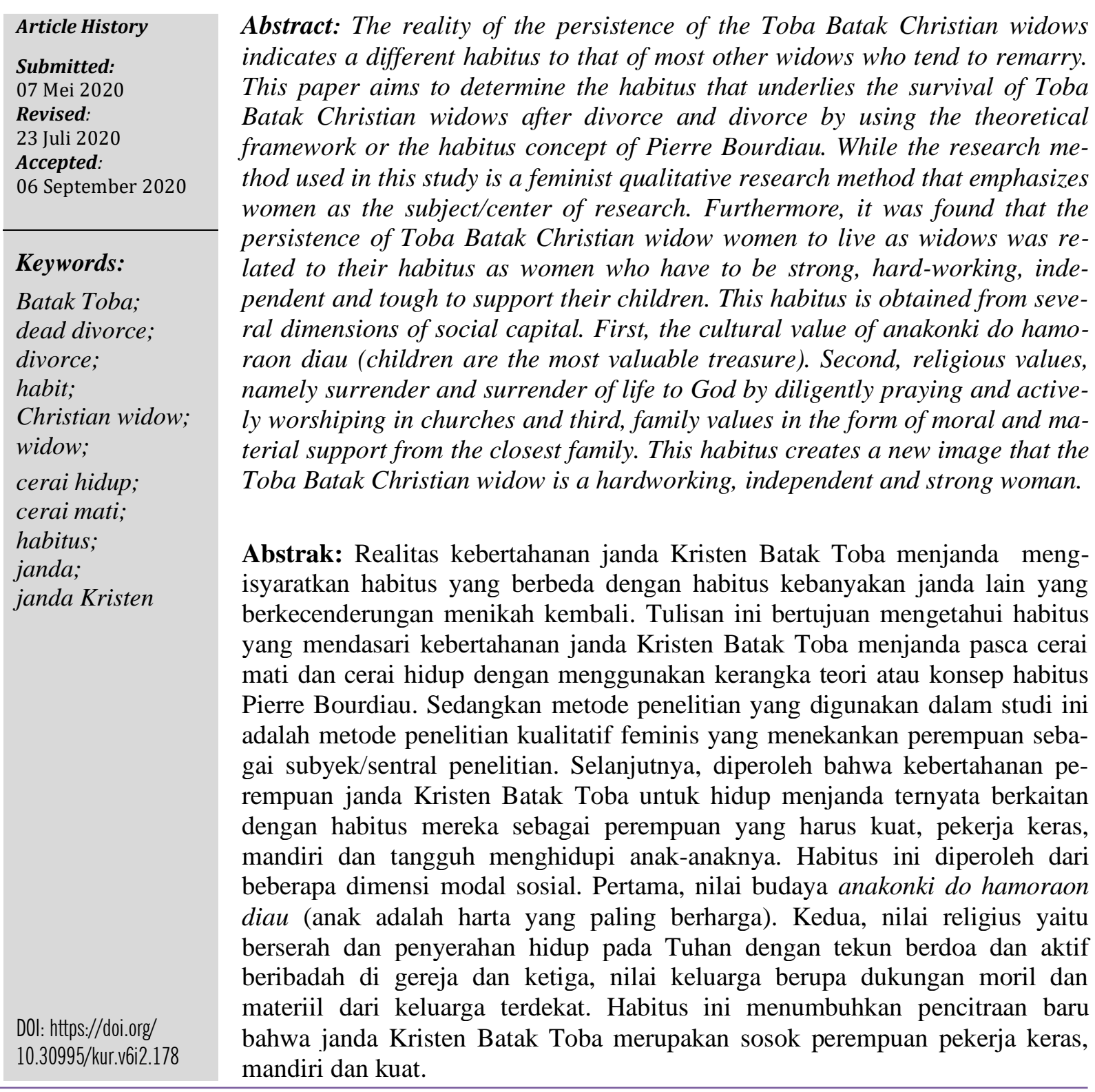

\section{Pendahuluan}

Pembahasan status perempuan mengenai perkawinan dikategorikan atas status perempuan menikah, tidak menikah dan janda. Secara khusus status janda menerangkan status perempuan menikah namun tidak memiliki suami. Secara umum sebutan janda pada perempuan sangat 
rentan dengan tindak kekerasan mulai dari verbal sampai simbolik. Begitu pula kedudukan janda dalam berbagai masyarakat atau daerah seringkali dihubungkan dengan stigma maupun stereotipe yang tidak menyenangkan. Pemberian stigma dan stereotype yang buruk pada diri janda menimbulkan rasa tidak nyaman pada perempuan sehingga kebanyakan perempuan yang menikah tidak menginginkan hidupnya menjanda. ${ }^{1}$

Lahirnya stigma dan stereotipe pada janda dilatarbelakangi oleh nilai budaya masyarakat. Memang tidak sepenuhnya stigma buruk selalu diarahkan pada janda seperti kasus janda di masyarakat Aceh. Kedudukan perempuan janda di Aceh berbeda dengan janda di masyarakat lain. Janda di masyarakat Aceh lebih dihargai dan mendatangkan rasa simpati karena kebanyakan perempuan menjanda karena suami mereka menjadi korban perang konflik di Aceh. Demikian juga di daerah Jawa Barat atau masyarakat Sunda yang dianggap wajar dan umum apabila perempuan menjanda di usia muda karena praktik kawin usia muda yang diikuti dengan tradisi kawin cerai. Sebaliknya predikat janda pada perempuan Jawa berdampak pada stigma berupa pandangan serta sorotan yang buruk. Janda di masyarakat Jawa dikonotasikan dengan pencitraan negatif berupa sebutan janda muda dan janda kembang. Pencitraan negatif atau stigma yang dialamatkan pada perempuan Jawa tidak terlepas dari konstruksi budayanya yang patriarkis yang menempatkan posisi perempuan di bawah laki-laki terlebih

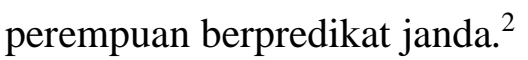

Masyarakat memberikan variasi pencitraan tentang janda, sebagaimana halnya dengan pencitraan janda Batak Toba. Perempuan janda Batak Toba dihadapkan dengan stigma dan juga rentan mengalami tindak kekerasan baik verbal maupun simbolik. Istilah lokal dari pencitraan negatif perempuan janda Batak yaitu maponggol uluna atau perempuan yang terpotong kepalanya. ${ }^{3}$ Pada sisi lainnya, citra positif ada pada janda Batak yaitu mereka dipandang sebagai single mother yang tangguh, mandiri dan berjuang keras menghidupi keluarganya. Artinya, ada dualitas nilai yang melekat pada diri janda Batak Toba. ${ }^{4}$

Berbicara tentang realitas perempuan janda di masyarakat Batak Toba adalah berbicara mengenai perempuan yang sudah tidak bersuami atau sering dikaitkan dengan istilah single mother. Ada dua penyebab perempuan menjanda yaitu kematian suami (cerai mati) dan perceraian (cerai hidup). Janda di masyarakat Batak disebut ina namabalu. ${ }^{5}$ Pembahasan kedudukan perempuan janda atau ina namabalu di masyarakat Batak Toba harus didudukkan dalam

\footnotetext{
${ }^{1}$ Taqwa dan Sudewo, "Kekerasan Simbolik pada Perempuan Janda di Kabupaten Sidoarjo”, Jurnal Paradigma Vol.04 No.03 (2016) : 1-8. Parker and Creese, "The Stigmatisation of Widows and Divorcees (Janda) in Indonesian Society", Jurnal Indonesia and The Malay World, Vol.44, No. 128, (2106) :1-6. Noer, KU, "Land, Marriage and Social exclusion: the case of Madurese exile widow", Jurnal International Congress on Interdisciplinary Business and Social Sciences (ICIBSoS 2012), Procedia-Social and Behavioral Sciences 65, (2012)180-185.

${ }^{2}$ Nur Hanna, Salinah, “Janda dari masa ke Masa: Upaya Keluar dari Kelindan Kekerasan” dalam Jurnal online Rifka media No.50 “Janda dari Mitos ke Mitos: Melacak Akar Kekerasan (2012): 18-12.

${ }^{3}$ Gultom, SDA, "Resistensi Janda Batak Terhadap Dominasi System Patriarki Budaya Batak Di Surabaya", tesis (2018):3.

${ }^{4}$ Nurjannah and R Dewi, The Role of Batak Tobanese women as parengge-rengge to enhance the living standards of family at Pajak Horas in Pematang SIantar City, IOP Conference Series: Earth and Environmental Science, ( 2018): 1-9.

${ }^{5}$ Gultom, SDA, "Resistensi Janda Batak Terhadap Dominasi System Patriarki Budaya Batak Di Surabaya", tesis (2018):4.
} 
kerangka masyarakat Batak Toba yang dikenal dengan sistem kekerabatan patrilineal. Masyarakat patriarkhal seringkali dihubungkan dengan sistem kekuasaan yang patriarkhi. ${ }^{6}$

Masyarakat berbudaya patriarkhat merupakan tempat yang subur lahirnya stereotipe maupun stigma yang tidak adil terhadap perempuan, terlebih perempuan janda di masyarakat Batak Toba. Dalam budaya patriarkhat Batak Toba menempatkan kedudukan perempuan yang tidak sama dengan kedudukan laki-laki. Hal ini diperlihatkan melalui sejumlah ketentuan atau norma-norma adat sebagai bentuk ketentuan hukum yang tidak tertulis (non-formal). Dalam ketentuan adat masyarakat Batak Toba memberikan posisi sosial laki-laki yang lebih tinggi daripada perempuan. Misalnya, penentuan keturunan garis keluarga serta pemilikan harta warisan selalu jatuh pada pihak laki-laki sementara perempuan tidak diperkenankan mewariskan garis keturunan dan juga memiliki hak pewarisan harta. Posisi inilah yang memperlihatkan bahwa kedudukan perempuan sangat tergantung dan bergantung pada kedudukan laki-laki dalam konteks sebagai ayah dan suami atas diri perempuan.

Pembahasan kedudukan perempuan dalam struktur budaya Batak Toba pada intinya menunjukkan kedudukan perempuan yang lemah dan bersifat ambigu. Istilah ambigu atau kedudukannya tidak jelas merupakan pemaknaan yang dialamatkan pada perempuan Batak Toba. ${ }^{7}$ Menurut Irianto (2003) dalam Baiduri perempuan Batak ketika belum menikah mengikuti marga dari ayahnya dan setelah menikah ia tetap masih menyandang marganya dan sekaligus marga suaminya. Meskipun berhubungan dengan kedua marga ayah dan suaminya tetapi ia sebenarnya tidak pernah menjadi anggota penuh dari kedua marga tersebut. ${ }^{8}$

Sebagai reperesentasi masyarakat dengan sistem kekerabatan patrilineal, masyarakat Batak Toba memberikan legalitas serta otoritas yang sangat tinggi dan mulia pada laki-laki. Dalam masyarakat Batak Toba berlaku adat yang menempatkan kedudukan laki-laki lebih tinggi daripada perempuan. Laki-laki sebagai penerus keturunan melalui marga dan juga penguasaan terhadap harta warisan. Meskipun saat ini kecenderungan hak mewaris sudah mulai diberikan kepada anak perempuan di keluarga namun tampaknya tidak demikian dengan janda. ${ }^{9}$ Sampai sejauh ini belum ada studi dalam konteks hukum adat yang menyatakan bahwa janda Batak Toba memiliki hak mewaris ditengah masyarakatnya ${ }^{10}$ kecuali jika janda mau menggugat ke hukum Negara melalui Pengadilan Negeri. ${ }^{11}$

Dalam konteks adat, kedudukan janda Batak Toba dapat ditelusuri melalui hukum adat masyarakat Batak Toba. Secara hukum adat yang berlaku di masyarakat Batak Toba diatur mengenai kedudukan janda ditinggal mati dan janda karena cerai hidup. Pada janda cerai hidup tanpa anak dan anak sepanjang ia tidak menikah tetap dianggap sebagai bagian

${ }^{6}$ Sihotang, AP dkk. "Reposisi Kedudukan Janda (Cerai Mati) Dalam Hukum Waris Adat Batak Dalam Perspektif Gender", Journals.usm.ac.id (2015):181-197. Munthe, HM. "Patriarchal Reproduction of Women Gender Ideology in The Pakpak Family”, Indonesia, Junior Scientific Researcher Journal, Vol.V, No.2. (2019) : $1-15$.

${ }^{7}$ Baiduri, Ratih, "Laki-laki Feminis dalam Rumahtangga dan Keluarga Perempuan Pedagang Batak Toba (Inang-Inang) di kota Medan”, Konferensi Internasional Feminsme: Persilangan Identitas, Agensi dan Politik (20 Tahun Jurnal Perempuan) (2016):1302-1325.

${ }^{8}$ Ibid.

${ }^{9}$ Nainggolan,TES, “ Kedudukan Anak Perempuan Dalam Hukum Waris Adat Pada Masyarakat Toba Di Kecamatan Pontianak Kota Di Kota Pontianak”, (2016): 67.

${ }^{10}$ Pardede, Erlina., "Menelusuri Bentuk-bentuk Kekerasan Perempuan di Masyarakat Adat" ( 2010):112.

${ }^{11}$ Lubis, Fitria Olivia Azizah, "Kedudukan Janda dalam Hukum Waris adat Batak" (2007):4 
dari keluarga besar suaminya. Apabila mereka menikah lagi pada orang lain maka hak asuh anak diambil alih oleh keluarga suami dan otomatis hubungannya putus dengan keluarga suaminya. Sementara janda yang ditinggal mati akan menjadi bagian keluarga atau kerabat suaminya demikian juga anak-anak yang diperoleh dari perkawinan. Harta warisan yang ditinggalkan suami jatuh pada anak laki-lakinya. Perempuan janda hanya sebatas memiliki hak mengelola dan memanfaatkan warisan tersebut untuk memenuhi kebutuhan hidupnya dan anak-anaknya. Jika anak-anak sudah dewasa secara hukum otomatis warisan tersebut jatuh pada anak laki-laki yang paling tua. Jika janda tersebut tidak memiliki anak atau hanya punya anak perempuan maka harta warisan biasanya dikuasai atau diwarisi pihak keluarga laki-laki.

Aturan lain dari adat Batak Toba mengenai janda diperbolehkan menikah lagi namun janda tersebut diharuskan menikah dengan saudara laki-laki atau kerabat laki-laki dari almarhum suaminya. Jika tidak ada saudara kandung dari mendiang suami akan diupayakan kerabat terdekat asalkan satu marga dengan mendiang suami terdahulunya. Dengan demikian para janda tetap berada dan terikat dengan ikatan kekerabatan dari marga suaminya. Perkawinan janda dengan laki-laki yang berasal dari keluarga suami sangat dianjurkan demi menjaga warisan tidak berpindah tangan, melindungi martabat dan kehormatan perempuan janda serta keberlangsungan pemeliharaan dan pengasuhan anak-anak. ${ }^{12}$

Keberlakuan adat mengenai kedudukan perempuan janda yang sedemikian umumnya diadopsi serta dipraktikkan pada kalangan masyarakat Batak Toba sampai saat ini. Namun ternyata tidak semua janda Batak Toba bersedia mengikuti dan menjalankan aturan adat yang sedemikian terutama pada kalangan perempuan janda yang memiliki latarbelakang keyakinan Kristen di kelurahan Titi Rantai, Medan. Perempuan Kristen Batak Toba yang menyandang predikat janda di kelurahan ini cenderung memilih hidup tetap menjanda pasca cerai mati dan cerai hidup. Artinya, mereka memilih hidup menjanda ketimbang menikah lagi. Pilihan hidup janda Kristen Batak Toba untuk tetap menjanda seakan-akan bertolak belakang dengan kondisi perekonomian mereka yang relatif lemah dan dikategorikan sebagai keluarga miskin. Posisi perempuan menjanda berkonsekuensi pada tanggungjawab mereka sebagai kepala keluarga. Realitas perempuan janda Kristen Batak Toba di Kelurahan Titi Rante, Medan adalah realitas perempuan kepala keluarga yang miskin, berusia muda dan paruh baya. Perempuan menjanda di usia muda dan paruh baya serta berperan sebagai single mother seakan-akan tidak menggoyahkan mereka untuk menikah kembali. Bertolak dari fenomena kebertahanan janda Kristen Batak Toba menjanda mengisyaratkan sisi habitus perempuan yang menarik dikaji dengan menggunakan kerangka teori habitus Pierre Bourdiau.

\section{Metode Penelitian}

Studi ini pada intinya menggunakan metode kualitatif-feminis. Sementara data lapangan yang diperoleh dalam penelitian akan dianalisis dengan menggunakan teori habitus yang dipopulerkan oleh Pierre Bourdiau. Metode kualitatif yang feminis dalam studi ini dimaknai hanya sebagai pendekatan yang berupaya mengangkat pengalaman hidup perempuan maupun suara perempuan. Pengalaman hidup dan suara perempuan janda Kristen Batak Toba juga dianggap

${ }^{12}$ Sihotang, AP dkk," Reposisi Kedudukan Janda (Cerai Mati) Dalam Hukum Waris Adat Batak Dalam Perspektif Gender", journals.usm.ac. (2015): 181-197. 
menarik serta penting memberi warna, memperkaya khasanah penelitian yang berkaitan dengan perempuan. ${ }^{13}$

Studi kualitatif mengenai kehidupan janda Kristen Batak Toba yang menjanda pasca cerai mati dan cerai hidup dilakukan di kelurahan Titi Rantai kota Medan. Alasan penentuan lokasi dikarenakan secara data kependudukan yang tersedia di kota Medan daerah ini merupakan wilayah hunian etnis Kristen Batak Toba yang terbanyak dibandingkan dengan wilayah kelurahan Medan lainnya (Kecamatan Medan Baru Dalam Angka, 2015). Kehadiran jumlah penduduk etnis Batak Toba terutama dari kalangan Kristiani yang bermukim di daerah ini diperkuat dengan banyaknya fasilitas ibadah gereja tradisional kesukuan HKPB (Huria Kristen Protestan Batak), GKPS (Gereja Kristen Protestan Simalungun GBKP (Gereja Batak Karo Protestan). Selain itu di wilayah ini relatif banyak dijumpai paguyuban berbasis ikatan marga dan kelompok Serikat Tolong Menolong (STM) yang berorientasi keagamaan (Kristen) dan kesukuan. Keberadaan gereja dan paguyuban sosial budaya suku Batak Toba yang relatif banyak menjadi pintu masuk untuk mendapatkan informan perempuan janda Kristen Batak Toba yang tercatat sebagai anggota paguyuban marga maupun kelompok serikat tolong menolong berbasis kegamaan (Kristen).

Setelah melewati proses pendekatan yang intens dengan menggunakan strategi solidaritas sesama perempuan, dibarengi juga dengan kesabaran akhirnya ada lima orang perempuan janda Kristen Batak Toba berbagai marga atau boru yang bersedia bekerjasama sebagai informan studi. Kriteria penentuan informan ditetapkan sesuai dengan kepentingan kajian yaitu perempuan janda Kristen Batak Toba yang berstatus kepala keluarga (pekka) dengan rentang usia muda (30-40) dan paruh baya (40-50) tahun serta berada pada kategori keluarga miskin perkotaan. Nama informan sengaja disamarkan sebagaimana yang ditampilkan dalam tabel di bawah ini.

Tabel 1: Data Usia dan Marga (boru) informan Perempuan Janda Batak Toba

\begin{tabular}{lcl}
\hline Nama Janda & Usia (tahun) & Marga $($ boru $)$ \\
\hline Masta & 38 & Sitanggang \\
\hline Sondang & 40 & Simarmata \\
\hline Rauli & 45 & Simbolon \\
\hline Netty & 50 & Tambunan \\
\hline Lydia & 35 & Saragih \\
\hline
\end{tabular}

Selanjutnya dari kelima informan penelitian ini dilakukan pengumpulan data melalui wawancara mendalam yang terstruktur dan tidak terstruktur mulai dari awal tahun 2018 sampai awal tahun 2019. Setiap hasil wawancara direkam dan dibuat dalam bentuk transkrip per masing-masing informan. Pelaksanaan wawancara mendalam yang dilakukan berlangsung dalam jangka waktu setahun menggunakan pedoman wawancara mendalam dengan cakupan topik sejarah hidup perempuan menjanda, penyebab menjanda, alasan tidak menikah lagi, pekerjaan, masalah-masalah hidup, suka dan duka sebagai janda, stigma menjanda dan peran single mother.

\footnotetext{
${ }^{13}$ Reinharz, Shulamit." Feminist Methods in Social Research", (1992) :18. Arrivia, Gadis. "Pentingnya Metodologi Feminis”, Jurnal Perempuan Nomor 48 (2006): 4-7.
} 
Pengumpulan data tidak selalu mulus sebab ada hambatan selama proses wawancara mendalam. Hambatan wawancara terjadi disebabkan kondisi psikologis dan suasana hati dari sebagian perempuan janda yang lagi peka dan sensitif. Ini sering terjadi apabila mereka sedang memiliki masalah terutama masalah ekonomi. Dalam kondisi yang sedemikian peneliti harus tanggap dan melakukan solusi dengan memberikan sembako seperti beras, gula, minyak makan, atau ikan asin sebagai bentuk rasa simpati dan empati terhadap problema para janda ini sehingga hambatan pelaksanaan wawancara biasanya dapat teratasi.

Selanjutnya seluruh hasil wawancara atau data lapangan yang sudah ditranskripkan berdasarkan informan penelitian kemudian disusun menurut kategorisasi topik wawancara mendalam sesuai dengan pedoman wawancara. Proses kategorisasi data lapang disertai pula dengan proses reduksi data yang mengacu pada tujuan penelitian yaitu ingin mengetahui konstruksi habitus kebertahanan menjanda pada janda Kristen Batak Toba.

Penting untuk dijelaskan bahwa proses pengerjaan kategorisasi data lapangan yang sudah dikerjakan sesuai dengan topik-topik wawancara mendalam dilakukan secara bersamaan dengan proses reduksi data. Artinya semua data yang diperoleh di lapangan dipilah-pilah kembali dengan berpedoman pada tujuan pokok penelitian. Setelah melakukan kategorisasi dan reduksi data lapangan maka langkah berikutnya menganalisis dan menampilkan data sesuai dengan pilihan teori yaitu teori habitus Pierre Bourdiau.

\section{Hasil dan Pembahasan}

Berdasarkan hasil wawancara mendalam pada semua informan janda Kristen Batak Toba dapat dideskripsikan bahwa tidak satu pun perempuan ini yang mengingankan hidupnya menjadi janda apalagi menyandang predikat sebagai janda. Kedudukan perempuan janda dalam masyarakat Batak Toba sering diibaratkan perempuan yang mengalami penderitaan yang berlapis ganda (double problem). Mereka merupakan kelompok yang mengalami praktik subordinasi oleh hegemoni budaya patriarki yang menempatkan dominasi laki-laki dalam segala aspek kehidupan masyarakat Batak Toba terutama dalam hal adat. Sementara para janda juga harus menerima perlakuan subordinasi dari sesama perempuan yang mengadopsi nilai-nilai patriarki. Perempuan bernilai patriarki bisa direpresentasikan dalam sosok ibu, ibu mertua, ipar perempuan dan juga perempuan lainnya yang memiliki hubungan langsung maupun tidak langsung dengan janda tersebut. ${ }^{14}$

Setidaknya anggapan miring dan pandangan melecehkan juga dialami oleh para janda Kristen Batak Toba yang menjadi informan dalam studi ini. Pandangan dan perlakuan yang tidak menghargai keberadaan janda ternyata bukan menjadi alasan para perempuan janda Kristen Batak Toba ini untuk cepat-cepat mengakhiri status janda dengan berupaya memiliki suami baru melalui jalan menikah kembali. Sebaliknya perempuan janda Kristen Batak Toba yang tinggal di kelurahan Titi Rantai, Medan lebih memilih hidup menjanda atau tetap bertahan menjadi janda dalam hitungan waktu yang cukup lama. Habitus kebertahanan perempuan Kristen Batak Toba menjanda dapat ditelusuri melalui sejarah atau riwayat mereka menjadi janda. Riwayat dan penyebab perempuan Batak Toba menjanda secara singkat ditampilkan dalam profil informan dalam tabel di bawah ini.

\footnotetext{
${ }^{14}$ Gultom, SDA, "Resistensi Janda Batak Terhadap Dominasi System Patriarki Budaya Batak Di Surabaya", Tesis (2018): 3. Munthe, HM. "Patriarchal Reproduction of Women Gender Ideology in The Pakpak Family”, Indonesia, Junior Scientific Researcher Journal, Vol.V, No.2. (2019): 1-15.
} 
Tabel 2: Profil Informan Perempuan Janda Batak Toba

\begin{tabular}{|c|c|c|c|c|c|c|}
\hline 1 & 2 & 3 & 4 & 5 & 6 & 7 \\
\hline Janda & $\begin{array}{c}\text { Usia } \\
\text { (Tahun) }\end{array}$ & $\begin{array}{l}\text { Marga } \\
(\text { boru })\end{array}$ & $\begin{array}{c}\text { Lama } \\
\text { Menjanda } \\
\text { (tahun) }\end{array}$ & $\begin{array}{l}\text { Penyebab } \\
\text { Menjanda }\end{array}$ & $\begin{array}{c}\text { Jumlah } \\
\text { Anak } \\
\text { (orang) }\end{array}$ & Pekerjaan \\
\hline Masta & 38 & Sitanggang & 8 & Kematian & 3 & $\begin{array}{l}\text { Pedagang Pakaian Bekas di } \\
\text { pasar tradisional }\end{array}$ \\
\hline Sondang & 40 & Simarmata & 12 & Kematian & 2 & Pekerja Salon \\
\hline Rauli & 45 & Simbolon & 11 & Perceraian & 3 & $\begin{array}{l}\text { Pegawai Rumah Makan } \\
\text { Kuliner daerah Batak }\end{array}$ \\
\hline Netty & 50 & Tambunan & 15 & Perceraian & 3 & Buruh Cuci dan Tukang Urut \\
\hline Lydia & 35 & Saragi & 7 & Kematian & 3 & Pengemudi Becak Mesin \\
\hline
\end{tabular}

Riwayat Menjanda: Penelantaran, Stigma dan Konflik pada Janda Kristen Batak Toba Tabel 2 menjelaskan riwayat perempuan menjanda diperlihatkan dalam kolom 4 yaitu data keterangan tentang lamanya perempuan menjanda. Pada kolom tersebut terdapat variasi data mengenai lamanya perempuan menjalani hidup menjanda. Ibu Netty boru Tambunan merupakan perempuan yang terlama hidup menjanda yakni sekitar 15 tahun, diikuti ibu Sondang boru Simarmata sudah menjanda 12 tahun, ibu Rauli boru Simbolon juga menjanda 11 tahun, ibu Masta boru Sitanggang menjanda 8 tahun dan terakhir ibu Lydia Saragi baru menjanda sekitar 7 tahun. Ada keterkaitan atau korelasi positif antara data informan mengenai lama menjanda dengan data usia. Artinya data ini mencerminkan bahwa usia informan janda yang paling tinggi memiliki latarbelakang masa menjanda yang lebih lama. Demikian pula sebaliknya informan perempuan janda yang berusia lebih muda usianya diikuti dengan masa menjanda yang lebih rendah waktunya. Data yang lebih detail diperlihatkan dalam kolom 2.

Profil berikutnya keterangan mengenai penyebab perempuan menjanda ditampilkan dalam kolom 5. Sesuai data dalam kolom 5 pada tabel ini menjelaskan ada dua hal penyebab perempuan menjanda yaitu kematian dan perceraian. Tiga perempuan menjadi janda karena suaminya meninggal atau cerai mati. Penyebab kematian suami cukup bervariasi yaitu karena penyakit dan kecelakaan lalu lintas. Sementara dua perempuan menjadi janda karena bercerai dengan suaminya. Ketidakharmonisan perkawinan menjadi bibit perceraian karena suami mereka berselingkuh dan juga sekaligus pelaku tindak KDRT (kekerasan dalam rumah tangga). Perbuatan berselingkuh dan tindak KDRT oleh mantan suami pada dua perempuan janda yaitu Ibu Netty boru Tambunan dan Ibu Rauli boru Simbolon menjadi alasan utama terjadinya perceraian. Kedua perempuan ini sudah tak sanggup menahan sakit hati dan kekerasan fisik yang sudah menahun dilakukan oleh bekas suaminya sehingga mendorong keluarga asal janda ini bertindak. Setelah kedua perempuan ini dipisahkan dari suaminya beberapa waktu kemudian pihak keluarga perempuan ini mengurus perceraian.

Pihak keluarga ibu Netty boru Tambunan menempuh perceraian jalur kekeluargaan dan juga jalur hukum. Kebetulan keluarga Ibu Netty mempunyai pengacara dan juga berprofesi sebagai aktivis Lembaga Bantuan Hukum untuk perempuan yang bersedia membantu melakukan proses gugat cerai. Sementara ibu Rauli hanya melakukan perceraian dengan pihak bekas suami dengan menggunakan jalur kekeluargaan saja. Artinya secara ikatan perkawinan ibu Rauli boru Simbolon sudah putus dengan suaminya. Namun ikatan kekeluargaan dengan keluarga suaminya belum putus karena ada keturunan yang dihasilkan dari perkawinan. Semua 
hak asuh anak jatuh ke tangan ibu Netty boru Tambunan dan ibu Rauli boru Simbolon. Secara adat ikatan kekeluargaan kedua perempuan ini dengan keluarga suaminya belum putus namun faktanya tidak ada kepedulian baik moril maupun materiil dari pihak keluarga mantan suaminya terhadap anak-anak mereka.

Keputusan bercerai yang digagas pihak keluarga kedua perempuan janda ini sebenarnya tidak langsung menyelesaikan persoalan antara kedua perempuan janda ini dengan pihak keluarga suaminya. Hasil perkawinan berupa anak-anak yang menjadi penerus keturunan secara adat seharusnya menjadi tanggungjawab pihak keluarga bekas suami. Proses tarik ulur dalam hal pertanggungjawaban biaya hidup keluarga kedua perempuan janda ini dengan keluarga bekas suaminya membuat mereka tersiksa dan menderita. Dampak perceraian sesungguhnya sangat menghancurkan psikologis kedua janda ini. Tidak hanya sebatas psikologis saja tapi ditambah lagi dengan masalah ekonomi janda yang terpuruk karena mereka tidak punya pekerjaan untuk menghidupi anak-anaknya. Beratnya beban psikologi dan ekonomis yang ditanggung kedua janda ini membuat mereka sampai depressi. Ironisnya, pihak keluarga bekas suami yang mengetahui keadaan depressi pada ibu Netty dan ibu Rauli samasekali tidak mau tahu bahkan merespon dengan kata-kata menyudutkan seperti "nga dijalo be sapata naroa" artinya sudah diterimanya karma buruk. Pihak keluarga bekas suaminya mengatakan bahwa depressi yang dialami janda ini karena berani bercerai dengan anak mereka. Bekas mertua (perempuan) kedua janda ini kesal dan malu atas keberanian mereka menceraikan anaknya.

Kedua perempuan janda ini mengisahkan pahit dan sakitnya perlakuan yang dialaminya dari pihak keluarga suami terlebih mertua perempuannya. Mereka tidak mau mensubsidi dan mengambil alih tanggungjawab ekonomi pada anak-anak mereka yang juga sesungguhnya adalah cucunya sendiri. Penelantaran keluarga yang dilakukan oleh keluarga bekas suaminya dimaknai sebagai ketidakkonsistenan atau pembangkangan terhadap nilai-nilai adat Batak yang memberlakukan kedudukan janda yang semestinya dalam masyarakat Batak.

Praktik penelantaran keluarga pihak bekas suami pada perempuan janda cerai paling pahit dan menyakitkan dialami oleh ibu Netty boru Tambunan. Perceraian yang terjadi pada dirinya ternyata menghasilkan konflik yang tak berkesudahan. Ia menceritakan kalau dia dulu menikah dengan suaminya yang berasal dari keluarga berpunya di kota asalnya di Pematang Siantar. Kemudian ia ikut suaminya yang dipercaya membuka cabang usaha bisnis transportasi orangtuanya di Medan. Ternyata suaminya ini punya tabiat suka main perempuan dan berjudi. Jika ibu Netty menegur suaminya yang tertangkap basah "main perempuan" bukannya mengaku salah malah membentak dan sering main pukul terhadap bu Netty bahkan itu sering terjadi di depan anak-anaknya. Dari perkawinannya ibu Netty dikaruniai anak tiga orang satu laki-laki dan dua anak perempuan. Mereka bercerai tatkala anak-anak masih kecil. Ibu Netty mengisahkan bagaimana perlakuan arogan yang diterima dari bekas mertua perempuannya. Ibu ini menuturkan kembali perkataan mertuanya yang tidak dilupakannya dan ia tak kuasa membendung airmatanya mengingat ucapan mertua perempuannya ini:

Apa dasar kau minta uang belanja ke kami... kalau berani bercerai beranilah membiayai anak-anakmu. Seperti apapun buruk dan jahatnya suamimu..kau harus mengalah dan 
pandai-pandai menghadapinya. Biar tahu kau... bukan kau yang kumau jadi menantuku tapi karena kau yang "menggatal" pada anakku jadi bunting duluanlah kau.

Selanjutnya ibu Netty dengan secara terbata-bata menyampaikan perkataan mertuanya yang sangat menusuk hatinya bahkan ia saat itu hampir pingsan:

...daripada kami malu terpaksa kali kami kawinkan kalian. Tanggungjawabilah anakanakmu itu kalau bapak si Donda (menyebut panggilan bekas suaminya) bisanya dia kawin lagi bukan kayak kau....siapa rupanya laki-laki yang mau kawin dengan perempuan bodoh seperti kau.

Perkataan bekas mertua perempuannya merupakan penghinaan yang sangat melukai hati bu Netty dan sampai saat ini tidak bisa dilupakannya. Ia bisa bertahan hidup sampai sejauh ini karena masih ada support moril dan materiil yang diberikan oleh pihak keluarga inti bu Netty. Di samping itu bu Netty bekerja sebagai tukang urut dan juga merangkap buruh cuci di perumahan elit di daerah Titi Rante, Medan. Pekerjaannya sebagai tukang urut dan buruh cuci dilakonin selama 8 tahun dan berbuah manis yaitu anaknya yang pertama perempuan diterima kuliah beasiswa di STAN (Sekolah Tinggi Akuntansi Negara) dan sudah menjadi PNS. Anaknya yang lain sekolah dibangku SMA dibiayai oleh gereja tempat ia menjadi jemaat. Anaknya yang paling kecil masih SMP dibiayai oleh anaknya yang sudah bekerja.

\section{Kebertahanan Menjanda Pada Janda Kristen Batak Toba}

Kebertahanan menjanda di kalangan perempuan janda Kristen Batak Toba ditenggarai dengan latarbelakang habitus yang mereka miliki. Realitas perempuan Kristen Batak Toba yang bertahan atau tetap menjanda menghadirkan suatu konstruksi habitus yang berbeda dengan konstruksi habitus janda dari masyarakat atau daerah yang lain. Misalnya habitus kawin cerai dan pernikahan dini di kalangan perempuan Jawa Barat. Kemudian habitus menikah kembali pada perempuan janda Jawa sebagai strategi menghindari stigma maupun stereotipe di masyarakatnya. $^{15}$

Berbicara mengenai habitus perempuan janda adalah membincangkan sebuah konsep atau teori habitus yang digagas oleh tokoh sosiologi postmodernisme Pierre Bourdiau. Menurut Bourdiau habitus perempuan (janda) menjadi penting untuk dideskripsikan sebab habitus mampu menjelaskan sistem skema persepsi dan apresiasi terhadap praktik-praktik, strukturstruktur kognitif dan evaluatif yang mereka peroleh lewat pengalaman berada pada sebuah posisi sosial yang berlangsung lama. Sistem kerja habitus ini mampu menghasilkan produksi praktik yang membuat seseorang memperoleh sebuah dunia akal-sehat sebagai sebuah dunia yang kelihatannya sudah terbukti dengan sendirinya. Oleh karenanya, seseorang akan mengklasifikasikan diri, menerima klasifikasi diri dan mempersepsi hubungan-hubungan praktik atau representasi dengan posisi ruang sosialnya. ${ }^{16}$

Bourdiau juga mengemukakan habitus sebagai teori yang mendamaikan agen dan struktur. Dalam artian bahwa habitus itu dimaknainya sebagai perjumpaaan agen dan struktur. Habitus dapat juga dimakani sebagai agen dan struktur itu sendiri dimaknai sebagai medan, ranah, arena (field). Pemaknaan yang lebih sederhana dapat diartikan juga bahwa teori habitus ini mengelaborasi dua unsur yang selalu ada dalam diri individu termasuk perempuan janda

\footnotetext{
${ }^{15}$ Nur Hanna, Salinah, “Janda dari masa ke Masa: Upaya Keluar dari Kelindan Kekerasan” dalam Rifka media No.50 “Janda dari Mitos ke Mitos: Melacak Akar Kekerasan” (2012): 8-12.

${ }^{16}$ Bourdieu, Pierre, "Choses Dites: Uraian \& Pemikiran (edisi terjemahan)" (2011): 175.
} 
Kristen Batak Toba. Masing-masing unsur tersebut adalah subjektivitas dan objektivitas. Unsur subjektivitas adalah segala nilai yang terlekat dan diproduksi dalam diri individu dan unsur objektivitas merupakan nilai-nilai yang berasal dari ranah atau medan di mana individu berada atau yang ditempatinya. Dalam diri individu ada dua unsur yang mengonstruksi skema pemikiran, kecondongan untuk berperilaku atau mempersepsi realitasnya. Semua ini bermuara dari dalam dirinya, maupun luar diri individu yang selanjutnya akan mempengaruhi cara pandang dan cara bertindak seorang janda (agen) mempersepsi keberadaan dirinya di dalam berbagai ranah yang ditempatinya. ${ }^{17}$

Realitas perempuan Kristen Batak Toba yang bertahan atau tetap menjanda menghadirkan suatu konstruksi habitus yang tersendiri. Masing-masing habitus bertahan menjanda ini terefleksikan melalui figur atau sosok perempuan janda Kristen Batak Toba yang melakoni hidup sebagai single mother yang berperan mengasuh anak dan mencari nafkah dalam rumah tangganya. Selain single mother mereka juga berstatus sebagai perempuan kepala keluarga (pekka).

Peran single mother dan status kepala keluarga perempuan (pekka) suka maupun tidak suka harus dilakoni janda Kritsen Batak Toba yang memang sudah tahunan menjalani hidup menjanda atau bertahan sebagai janda. Peran dan kedudukan ini pada akhirnya mengkonstruksi habitus tersendiri pada mereka. Habitus ini dipraktikkan dalam arena-arena (field) sosial seperti keluarga, lingkungan kerja, adat, lingkungan gereja dan masyarakat di sekitarnya. Peran sebagai single mother di kedudukan sebagai perempuan kepala keluarga berkonsekuensi dengan seluruh beban berat yang harus dipikul janda di keluarganya termasuk tanggung jawab mengasuh dan memenuhi kebutuhan anak-anaknya. Mereka harus bekerja keras sekuat tenaga agar bisa memenuhi dan mencukupi kehidupan ekonomi, psikologis maupun sosial anak-anaknya. Habitus single mother yang terlekat pada perempuan janda Batak Toba itu kemudian disertai dengan hadirnya habitus-habitus lain yaitu habitus perempuan yang sangat mencintai anak dan keluarganya, pekerja keras, ulet dan mandiri.

\section{Habitus Janda Kristen Batak Toba: Single Mother, Penyayang Anak, Pekerja Keras, Ulet dan Mandiri}

Takdir perempuan menyandang predikat janda pasca kematian dan perceraian harus dijalani oleh perempuan Kristen Batak Toba dalam keadaan menanggung rasa sakit, pilu, sepi dan pahit. Dalam kondisi psikologi yang terpuruk karena sudah hidup tanpa suami mereka juga harus berperan menjadi single mother. Mereka memiliki berbagai tanggung jawab terutama kewajiban terhadap anak-anaknya. Tanggung jawab perempuan janda untuk memenuhi segala kebutuhan hidup anak-anaknya dalam keluarga bukanlah suatu perkara yang mudah terlebih mengingat mereka menjanda di usia terbilang cukup muda serta memiliki anak-anak yang masih kecil. Seperti yang diutarakan oleh ibu Masta boru Sitanggang, ibu Sondang boru Simarmata dan ibu Lydia boru Saragi. Masing-masing perempuan ini menjadi janda karena suami mereka meninggal tatkala anak-anak mereka masih berusia balita, sekolah dasar (SD) dan paling tua saat itu duduk di bangku Sekolah Menengah Pertama (SMP).

\footnotetext{
${ }^{17}$ Taqwa dan Sudewo, "Kekerasan Simbolik pada Perempuan Janda di Kabupaten Sidoarjo”, Jurnal Paradigma Vol. 04 No.03 (2016) : 1-8.
} 
Ibu Masta boru Sitanggang (38 tahun) menceritakan bahwa ia menikah dengan almarhum suaminya karena pilihan hati dan ada rasa cinta. Ia menikah berusia sekitar 22 tahun. Menikah dengan almarhum suaminya mendapat restu dari orangtua dan demikian juga orangtua suaminya. Suaminya bekerja sebagai pedagang kain di salah satu pusat perdagangan kain di kota Medan dan ia hanyalah berperan sebagai ibu rumahtangga saja. Dari perkawinan itu lahir tiga anak, dua laki-laki dan satu perempuan. Menjalani kehidupan sebagai istri yang berbahagia hanya sekitar 8 tahun dan ia harus menerima pil pahit kehilangan suami yang terkena serangan jantung karena usaha dagangnya bangkrut dan ia ditipu rekan bisnisnya yang melarikan diri.

Kematian suami membuat ia shock dan sangat terpukul. Betapa tidak rumahtangga yang tadinya dijalani begitu manis dan indah harus berakhir dan ia suka tidak suka harus menjadi janda. Ibu Masta menuturkan kesedihannya dengan terisak sedih kalau si Ucok yang sekarang berusia 11 tahun tidak ingat wajah bapaknya sebab saat bapaknya meninggal ia berusia 3 tahun. Kepedihan hatinya menjalani hidup sebagai janda dilampiaskan dengan menyanyi sambil menangis. Sambil menyeka airmatanya ia menuturkan:

Jangan sampai ada perempuan hidup menjanda kayak aku ini. Bukan main sakitnya. Menyesal aku tidak sekolah tinggi sehingga menghidupi anak-anakkupun aku tidak mampu. Memang aku disubsidi ompungnya si Ucok (orangtua almarhum suaminya) dari kampung. Tapi itu hanya cukup untuk sekedar makan saja dan aku memang bersyukur masih dibantu mertuaku. Sementara kami tinggal di kota mengontrak rumah dan biaya sekolah anak-anak, listrik dan air harus kucari sendiri. Untung ada sikit modalku kupakai berdagang pakaian bekas di pasar pagi dan kalau ada hari pekan di pasar lain aku juga berdagang. Semua kulakukan demi anak-anakku dan rasa cintaku pada mendiang suamiku.

Kisah ibu Masta sebagai janda single mother yang berjuang menghidupi keluarganya dan tidak mau menikah atau bersuami lagi didasarkan oleh rasa cinta yang besar pada anakanaknya dan cinta yang kuat pada almarhum suaminya. Selain itu ia juga masih mendapat dukungan ekonomi dan sosial yang cukup berarti dari mertuanya atau pihak keluarga suaminya. Ia tidak terpikir menikah lagi meski kadangkala rasa sepi datang. Jika keinginan tersebut muncul, bu Masta melampiaskan hasrat dan kerinduannnya dengan menangis dan berdoa pada Tuhan sampai ia merasa lega dan tenang. Lebih jauh lagi ibu Masta juga menyadari kesibukannya sebagai pedagang kain bekas sudah cukup melelahkan ditambah lagi dengan mengurus ketiga anaknya yang masih bersekolah. Untuk mengatasi rasa kesepian dan hasrat biologisnya, bu Masta memilih lebih fokus bekerja dan selain itu ia melibatkan dirinya dalam berbagai kegiatan rohani di gereja dan rajin beribadah dalam kelompok doa ibu-ibu di lingkungan tinggalnya.

Kisah ibu Sondang dan ibu Lydia yang menjanda karena kematian suami agak sedikit berbeda dengan ibu Masta. Kedua janda ini tidak seberuntung ibu Masta yang memperoleh bantuan moril dan materiil dari pihak keluarga suaminya. Kedua janda ini bahkan sebaliknya cenderung mendapatkan perlakuan sakit hati dan diacuhkan oleh mertuanya dan juga anggota keluarga asal mendiang suaminya.

Ibu Sondang janda berusia 40 tahun memiliki tiga anak yang masih bersekolah di bangku SMP dan SMA. Ia berprofesi sebagai pekerja salon kecantikan di rumah kontrakan- 
nya dan ia juga menyediakan jasa "salon panggilan" dari rumah ke rumah bahkan ke luar kota. Janda ini berjuang keras bekerja tidak mengenal lelah demi mencukupi kebutuhan hidup keluarganya. Untuk memenuhi kebutuhan semua anak-anaknya ia rela berangkat tengah malam ke luar kota memenuhi jasa salon panggilan dari pelanggannya. Sesampainya di rumah dia hanya bisa istirahat sebentar kemudian membuka usaha salonnya sambil mengurus anakanaknya supaya tidak terlantar. Ibu Sondang mengibaratkan hidupnya seperti kuda boban (kuda beban) menghidupi kebutuhan anak-anaknya. Ia mengisahkan pahitnya hidup menjanda dan membesarkan anak-anaknya.

Suamiku meninggal karena kecelakaan lalu lintas. Waktu itu dia pulang kerja pagi karena shift malam di salah satu hotel besar di Medan. Sewaktu dia pulang bawa sepeda motor dan ditabrak truk kecepatan tinggi karena supirnya mabuk. Tak sempat dibawa ke rumah sakit sudah meninggal di tempat. Aku menikah di usia 24 tahun berdasarkan cinta dan cocok cara berpikir kami. Sempat menjalani hidup berumah tangga selama 8 tahun...sudah jalan 12 tahun aku jadi janda bu. Sebenarnya dulu perkawinanku kurang direstui mertuaku karena aku berasal dari keluarga miskin. Keluarga suamiku dulunya orang terpandang di kotanya (dia menyebut nama salah satu kota kabupaten di provinsi Sumatera Utara). Setelah kematian suamiku...aku dan anakku seakan-akan dibuang dari keluarga itu. Aku dan anak-anakku dibiarkan mere-ka merana dan tidak dibantu sepeserpun... apalagi saat itu aku masih sangat muda dan tak tahu mau kerja apa".

Ibu Sondang lebih jauh mengisahkan bagaimana ia harus menghadapi hujatan dan tuduhan kejam dari pihak keluarga suaminya seperti mertua dan ipar-iparn perempuanya. Mertuanya menuding bahwa kematian anaknya karena ibu Sondang boru-boru siboan luangon atau perempuan pembawa sial dan kurang serasi berumahtangga dengan anak mereka.

...sudah aku terpuruk karena kematian suamiku dituduh pula lagi aku sebagai penyebab kematiannya. Kurang apa lagi penderitaanku...kalau tak ingat anak-anakku masih kecil pingin bunuh diri aku tak kuat menerima sakitnya perlakuan mertua dan saudara iparku.

Dilema janda pada sosok ibu Sondang dihadapinya dengan hati yang hancur sambil menguatkan hati merawat anak-anaknya dan tetap taat berdoa dan beribadah. Meskipun hidupnya penuh dilemma, ibu Sondang berupaya mendekatkan diri pada Tuhan dan satu hal lainnya yang membuatnya bisa bersyukur karena ia memperoleh uang duka dan dana santunan dari tempat kerja suaminya dan juga dari gereja. Tidak itu saja dia juga memperoleh uang asuransi kecelakaan suaminya. Uang itu sangat berharga baginya. Sesuai nasihat dari keluarga dekatnya serta pendeta gereja tempat ia beribadah, ia menggunakan sebagian uang itu kursus salon kecantikan dan sisanya ia pakai mengontrak rumah dan biaya hidup anakanaknya. Sejak itu ia bisa bangkit dan sampai saat ini ia masih bisa menghidupi semua kebutuhan anak-anaknya. Ironisnya melihat kemandirian ibu Sondang menjalankan usahanya, datang kembali tudingan dari pihak keluarga suaminya dengan tuduhan ia menjual diri atau julukan boru-boru nasohasea atau "perempuan gatal" atau "perempuan perusak", dan juga dicemooh sebagai ina-ina naso tarpareso atau "ibu-ibu yang tak beres".

Sementara kisah ibu Lydia menjadi janda tidak jauh berbeda dengan ibu Sondang yaitu janda yang ditinggal mati suami karena sakit. Ibu Lydia menikah di usia 22 tahun dan hidup menjanda sekitar 7 tahun. Memiliki tiga anak yang masih Sekolah Dasar dan si sulung masih Sekolah Menengah Pertama. Mereka tadinya tinggal sekampung dan menikah atas dasar restu 
orangtua. Suaminya mengajak bu Lydia merantau ke Medan mencari pekerjaan dan memperoleh kehidupan yang lebih baik. Namun sangat sulit bagi suaminya memperoleh pekerjaan yang layak sehingga mereka memutuskan membeli beca mesin dan suaminya yang membawa beca mesin menunggu ada pekerjaan yang lebih baik. Selain mengemudikan becak mesin, suaminya juga bekerja serabutan sebagai tukang bangunan di luar jam menarik becak. Apabila sepi penumpang biasanya suaminya ikut kerja sebagai buruh bangunan. Ibu Lydia menuturkan dengan mata berkaca-kaca kenangan indah hidup bersama suaminya:

Meskipun hidup kami pas-pasan tapi kami sangat bersyukur dan bahagia. Apalagi kalau hari Minggu tiba...kami biasanya satu keluarga naik beca ke gereja. Suamiku yang bawa...aku dan anak-anak jadi penumpangnya. Beribadah bersama penuh sukacita dan sepulang ibadah kami biasanya jalan-jalan keliling kota sekalian menggembirakan anak-anak. Kebahagiaanku sebagai istri sirna karena suatu hari suamiku sepulang narik beca merasa kurang enak badan dan sesak bernafas. Memang dia perokok susah berhenti meskipun sudah sering kularang. Kupikir cuma masuk angin biasa dan kuurut badannya..kusuruh istirahat jangan narik beca dulu. Tak tahu apa2 aku... besoknya dia sudah meninggal...

Sejak itulah ibu Lydia hidup menjanda sampai sekarang. Mengingat usianya masih terbilang muda maka keluarganya dan juga keluarga suaminya menyarankan ia segera menikah supaya ada yang membantu mengurus anak-anak. Ibu Lydia belum siap dan tidak bisa melupakan ingatannya pada mendiang suaminya.

Sadar kalau ia sudah menjadi janda yang harus menghidupi anak-anaknya maka ia bangkit dan belajar sendiri membawa beca suaminya. Kemudian ia melanjutkan pekerjaan suaminya sebagai perempuan penarik beca. Ibu Lydia juga sempat mengisahkan bagaimana ia bisa menjadi seorang perempuan penarik beca:

Kebiasaan kami sebelum tidur berdoa dengan anak-anakku dan tengah malam aku dibangunkan suamiku dan dinasihatinya aku supaya jadi perempuan mandiri.. bawaklah becak kita itu supaya ada uang menyekolahkan anak-anak kita mak Ester (Ester adalah anak mereka paling sulung). Tatkala aku terbangun baru sadar kalau aku mimpi. Itulah jalanku menarik beca untuk membiayai hidup kami di Medan ini. Padahal disuruh mertuaku kami pulang ke kampung..disuruh kawin dengan adik almarhum suamiku. Disuruh kerja di ladang..aku tak mau.. tak kuat aku bekerja di ladang.

Menjalani pekerjaan sebagai perempuan penarik beca bukanlah hal yang mudah bagi seorang janda seperti dirinya. Ibu Lydia sering menerima godaan dan rayuan dari sesama teman penarik beca yang memang kebanyakan adalah kalangan laki-laki. Kata-kata seperti "lebih baik kau kawin atau jadi istri abang", atau kata-kata "sayang kali janda cantik mau menjadi tukang becak harusnya kerja di salon". Bahkan ada teman (laki-laki) sesama penarik becak yang terang-terangan menawari ibu Lydia pekerjaan sebagai penyedia jasa penghibur tamu laki-laki di suatu kafe. Namun semua godaan dan rayuan itu tidak dihiraukannya sama sekali. Ibu Lydia sangat mencintai almarhum suaminya dan demikian juga anak-anaknya. Kenangan yang indah tentang suaminya memberi ia semangat hidup serta rasa sayang yang luar biasa pada anak-anaknya membuat ibu Lydia bisa bertahan sampai saat ini.

Meski sering digoda atau dinakali oleh rekan sesama pengemudi becak, bu Lydia tidak terpengaruh maupun terusik. Ia memilih diam dan berdoa tatkala memperoleh perlakuan yang tidak menyenangkan dari teman-temannya. Janda ini selalu membesarkan hatinya dan berusa- 
ha sekuat tenaga mengemudikan becanya mencari penumpang agar anak-anaknya bisa makan dan memperoleh pendidikan yang baik. Syukurlah situasi tersebut tak berlangsung lama dialaminya sebab bu Lydia sudah memiliki banyak pelanggan setia anak-anak sekolah dan penumpang lanjut usia yang berasal dari gereja tempat ia beribadah. Dia memproleh penghasilan bulanan dan harian yang bisa menghidupi anak-anaknya bahkan pendidikan anak-anaknya dibiayai gereja karena ia memperoleh dana bantuan sebagai jemaat miskin.

Kisah janda lainnya perempuan single mother yang bertahan menjanda diperankan dalam sosok ibu Netty dan ibu Rauli. Kedua janda ini adalah janda yang cerai hidup dari suaminya. Sebagaimana yang sudah diuraikan terdahulu bahwa kedua janda ini "terpaksa" bercerai karena sudah tak kuat diselingkuhi dan sering dipukuli. KDRT terjadi kalau kedua janda ini mengetahui dan menegur suaminya "main perempuan". Keberadaan ibu Netty yang menjanda tanpa dukungan moril dan materiil dari pihak keluarga suaminya telah membangkitkan semangatnya untuk bisa mandiri dan berjuang membesarkan anak-anaknya. Meskipun sempat drop atau depresi namun ditopang oleh keluarga asalnya serta dukungan rohani dari gerejanya ia menjadi kuat dan bersemangat mengurus anak-anaknya dan membangun masa depan keluarganya.

Kisah janda yang berperan single parent juga dimainkan oleh ibu Rauli Simbolon. Nasibnya tidak jauh berbeda dengan ibu Netty yang terpuruk bahkan dia hampir mau bunuh diri minum racun karena sempat stress melihat kebejatan suaminya menyeleweng dan sering juga korban KDRT. Meskipun di awal perceraian dia mengalami keterpurukan psikologis, sosial dan juga ekonomi tetapi dia sadar harus bisa menjalankan tugasnya sebagai seorang ibu yang menghidupi anak-anaknya. Beruntung bu Rauli Simbolon masih punya orangtua dan juga saudara-saudara kandung yang sangat perduli dan selalu mendukung dan menghiburnya. Berselang dua tahun tertatih-tatih dan mencoba menata hidupnya yang hancur akhirnya dia dibantu kenalan keluarganya bekerja sebagai pegawai di rumah makan khas kuliner Batak yang terkenal di Medan. Selain bekerja sebagai pegawai ia juga memiliki keahlian membuat kue-kue tradisional yang bercita rasa tinggi untuk dijual di restoran tersebut dan dijual titip ke beberapa restoran lainnya. Salah satu penguat hidup bagi ibu Rauli boru Simbolon adalah anak-anaknya. Ibu ini menuturkan filosofi orang Batak mengenai nilai anak yaitu "Anakonki do hamoraon diau (anakku adalah kekayaan bagiku). Dengan semangatnya menceritakan filosofi adat Batak mengenai anak dia sampai terbawa emosi dan menangis sambil menyanyikan lagu Batak yang populer "anakonki do hamoraon di au”. Dia melanjutkan kata-katanya, "...kalau tak ada anak entah jadi apalah aku sekarang".

$\mathrm{Bu}$ Rauli menyadari dan bersyukur karena memiliki anak-anak yang akhirnya membuat ia menjadi kuat, bangkit terus berjuang. Kehadiran anak-anak sangat berharga bagi janda ini juga janda Kristen Batak Toba lainnya. Anak-anak merupakan sumber inspirasi, pemberi kekuatan dan penyemangat sehingga mereka memiliki semangat dan keyakinan bergumul dan bergelut melawan tekanan ekonomi maupun perlakuan yang menyakitkan dari orang-orang yang ada di sekitarnya. 


\section{Diskusi}

Kisah hidup janda Kristen Batak Toba sesungguhnya merupakan kisah hidup sebagian kecil perempuan janda di masyarakat Batak Toba dan juga perempuan janda lainnya di Indonesia. Sisi yang menarik dari kehidupan janda Kristen Batak Toba ditinjau dari analisis habitus perempuan yaitu timbulnya kesadaran serta keberanian dari diri mereka untuk menuturkan sisi yang paling rahasia dari hidupnya. Perceraian dan status janda merupakan persoalan perempuan Batak Toba yang sangat sensitif dan paling menyakitkan untuk diketahui orang lain. Tetapi dalam konteks kajian ini seakan-akan pemikiran seperti tidak berlaku pada perempuan janda Kristen Batak Toba. Ada kekuatan mereka ingin berbagi rasa duka maupun suka ketika mereka mengungkapkan pengalaman hidupnya. Harapan para perempuan janda ini, bahwa kisah hidup mereka semoga bermanfaat dan saling menguatkan bagi sesama perempuan terlebih perempuan janda lainnya di tempat lain.

Mengangkat dan mengungkap sisi terdalam dari sebagian besar kisah kehidupan janda Kristen Batak Toba dalam studi ini diibaratkan melihat sisi kelam dan pahit perempuan yang mampu diubah menjadi sisi terang dan sisi yang manis. Mempergunakan konsep Bourdiau tentang habitus, bahwa habitus kebertahanan perempuan Kristen Batak Toba menjanda menjadi single mother bukanlah suatu hal yang mudah. Di balik hati dan tubuhnya yang sakit menghadapi kerasnya arena atau ranah kehidupan, mereka harus sadar, tegar dan harus bangkit. Habitus janda yang dimaknai lemah, rapuh, pasrah, tak berdaya, terhina, berstigma, bercitra negatif, mampu diubah oleh para janda Kristen Batak Toba ini menjadi habitus perempuan yang tangguh, mandiri, bercitra positif dan keluar dari belenggu stigma. Perempuan janda Kristen Batak Toba harus menegakkan ekonomi rumahtangganya seorang diri, berjuang tanpa didampingi laki-laki atau suami. Mereka sebagian memutuskan tidak tergantung pada belas kasihan keluarga dari suaminya walaupun secara adat mereka memiliki hak untuk dilindungi. Sebagian besar perempuan janda Kristen Batak Toba yang menjanda secara adat memang nyata-nyata telah ditelantarkan. Tidak hanya sebatas penelantaran adat, ironisnya sebagian dari mereka juga mengalami perlakuan yang menyakitkan dari pihak keluarga suaminya karena dianggap sebagai pembawa sial, perempuan tak terpakai, perempuan yang tak beres, menantu yang tak diharapkan. Semua hinaan itu diterima dan disimpan dalam hati yang terdalam. Cukuplah airmata yang jatuh dan ratapan pilu yang tak boleh dilihat anakanaknya. Dalam ranah hidup yang sedemikian kejam mereka mencoba bertahan.

Perempuan janda Kristen Batak Toba boleh saja hatinya hancur tapi harga dirinya harus dipertahankan. Kisah hidup perempuan janda Kristen Batak Toba sesungguhnya merefleksikan sisi lain habitus janda yang berbeda dengan habitus janda lainnya. Setidaknya habitus tentang perempuan janda sebagai perempuan lemah, rapuh, dilecehkan dan disepelekan mereka ubah menjadi habitus perempuan keibuan yang kuat dan memiliki kepribadian yang tangguh. Perempuan Kristen Batak Toba yang menjanda tidak menyelesaikan persoalan hidupnya dengan memilih menikah atau bersuami. Mereka bertransformasi menjadi sosok perempuan dengan nilai-nilai keibuan yang bertanggungjawab dan setia memelihara anak-anaknya dengan sekuat daya tanpa harus tergantung pada laki-laki sebagai sosok suami. Terjadi pergeseran habitus janda menjadi habitus keibuan yang dinyatakan dalam wujud kemandirian mereka sebagi perempuan janda single mother yang berjuang menghidupi keluarganya sebagai 
kepala keluarga. Dalam pengertian lain perempuan janda Kristen Batak Toba mengubah citra perempuan yang lemah dalam belenggu dominasi budaya patriarki menjadi perempuan janda berhabitus tangguh dan kuat melawan hegemoni struktur patriarki.

Potret perempuan janda Kristen Batak Toba yang bertahan menjanda yang menjalani hidup yang berat dan nyaris tak mengenal kasihan ternyata tidak membuat mereka sebagai pihak yang goyah dan kalah. Habitus perempuan single mother dan perempuan kepala keluarga, tegar, pekerja keras dan mandiri yang dibangun dalam sosok diri janda merupakan habitus janda Kristen Batak Toba. Habitus janda yang sedemikian sekaligus juga menjadi modal utama bagi mereka yang diperlihatkan dan dipertaruhkan dalam segala ranah atau arena kehidupan yang secara jelas tidak selalu ramah pada mereka.

\section{Kesimpulan}

Kebertahanan janda Kristen Batak Toba menjanda diperlihatkan dalam sejumlah habitus yaitu sebagai single mother, pekeja keras, ulet dan mandiri. Habitus ini bersumber atau bekerja dari modal-modal sosial seperti nilai budaya, nilai religius dan nilai solidaritas keluarga asalnya. Habitus janda yang sedemikian telah mengubah citra negatif mengenai janda menjadi citra positif. Citra diri janda yang lemah dan teraniaya tidak serta mereka terima begitu saja. Sebaliknya, mereka aktif mengkonstruksi nilai baru dan citra baru bahwa janda bukanlah sosok yang lemah dan rapuh dalam wujud habitus perempuan yang tangguh, tegar, berani, kuat dan mandiri. Pergeseran habitus perempuan janda yang lemah dan rapuh menjadi habitus perempuan janda yang kuat dan tangguh bermuara pada kesadaran diri mereka, bahwa sebagai janda Kristen Batak Toba kekuatan hidupnya ada pada anak-anaknya. Semangat dan kekuatan hidup yang diperoleh janda dari anak-anaknya bertalian dengan budaya masyarakat Batak Toba yang sangat mengagungkan nilai anak dalam keluarga dengan ungkapan anakonki do hamoraon diau (anakku adalah kekayaanku). Nilai budaya inilah yang dijadikan kekuatan para perempuan Kristen Batak Toba untuk bangkit dari keterpurukannya sebagai seorang janda. Kekuatan para janda yang memiliki anak menjadi suatu modal yang sangat berharga untuk menegakkan kehormatannya sebagai perempuan yang mandiri dan tegar menghadapi pertarungan hidup di segala ranah atau arena kehidupan. Selain memiliki habitus tangguh karena memiliki anak-anak sebagai modal kekuatannya untuk bangkit maka habitus kebertahanan perempuan menjanda tidak terlepas dari modal-modal lainnya yakni kekuatan iman perempuan berserah pada Tuhan. Hal ini dilihat dari keterlibatan perempuan beribadah dan megandalkan Tuhan sebagai penopang hidup mereka. Indikasinya mereka rajin berdoa dan aktif ikut kumpulan doa. Selanjutnya adalah habitus kebertahanan menjanda bersumber dari modal sosial lainnya yaitu dukungan moril maupun materiil dari keluarga asal para janda.

\section{Ucapan Terima Kasih}

Terima kasih kepada Harmona Daulay, dari FISIP Unversitas Sumatera Utara, yang telah berkontribusi dalam mendampingi dan membantu selama penelitian; demikian juga kepada Napsiah, dari Universitas Islam Negeri Sunan Kalijaga, Yogyakarta yang turut berkontribusi memeriksa draft dan menyempurnakan penulisan artikel ini. Terima kasih juga kepada inanginang yang tangguh (janda Batak Toba), yang telah bersedia sebagai informan penelitian. 


\section{Referensi}

Arrivia, Gadis. "Pentingnya Metodologi Feminis", Jurnal Perempuan Nomor 48. Jakarta: Penerbit Yayasan Jurnal Perempuan, 2006

Baiduri, Ratih. "Laki-laki Feminis dalam Rumahtangga dan Keluarga Perempuan Pedagang Batak Toba (Inang-Inang) di kota Medan”, Konferensi Internsional Feminsme: Persilangan Identitas, Agensi dan Politik (20 Tahun Jurnal Perempuan), 2016. https://www.jurnalperempuan.org.

Bourdieu, Pierre. Choses Dites: Uraian \& Pemikiran (edisi terjemahan), Bantul: Kreasi Wacana, 2011.

Data Statistik Penduduk, Kecamatan Medan Baru dalam Angka, 2015

Gultom, SDA. "Resistensi Janda Batak Terhadap Dominasi System Patriarki Budaya Batak Di Surabaya", repository.unair.ac.id, 2018

Lubis, Fitria Olivia Azizah. "Kedudukan Janda dalam Hukum Waris adat Batak", Jurnal Lex Jurnalica, Vol.4. No.3, 2007. https://media.neliti.com/media/publications/17968-IDkedudukan-janda-dalam-hukum-waris-adat.pdf

Munthe, HM. "Patriarchal Reproduction of Women Gender Ideology in The Pakpak Family", Indonesia, Junior Scientific Researcher Journal, Vol. 5, No.2.pp.1-15,ISSN:2458-0341, http://www.jsrpublishing.com

Noer, KU. "Land, Marriage and Social exclusion: the case of Madurese exile widow", International Congress on Interdisciplinary Business and Social Sciences 2012 (ICIBSoS 2012), Procedia-Social and Behavioral Sciences 65, 180-185. www.sciencedirect.com>pil>pdf 180-185

Nainggolan, TOS. "Kedudukan Anak Perempuan Dalam Hukum Waris Adat Pada Masyarakat Toba Di Kecamatan Pontianak Kota Di Kota Pontianak," Program Pascasarjana Universitas Diponegoro, Semarang, 2005.

Nurjannah and R Dewi. The Role of Batak Tobanese womwn as parengge-rengge to enhance the living standards of family at Pajak Horas in Pematang SIantar City, IOP Conference Series: Earth and Environmental Science, 2018. https://www.researchgate.net>fulltext

Nur Hanna, Salinah. "Janda dari masa ke Masa: Upaya Keluar dari Kelindan Kekerasan" dalam Rifka media No. 50, 2012. Janda dari Mitos ke Mitos: Melacak Akar Kekerasan by Rifkamedia-issuu https://issue.com>rifkamedia>docs

Parker and Creese. "The Stigmatisation of Widows and Divorcees (Janda) in Indonesian Society", Vol. 44, No. 128 2016. 1-6, Indonesia and The Malay World, http://dx.doiorg/10.1080/13639811.2015.1111647

Pardede, Erlina. Menelusuri Bentuk-bentuk Kekerasan Perempuan di Masyarakat Adat, Sidikalang: Penerbit Pesada, 2010.

Reinharz, Shulamit. Feminist Methods in Social Research, New York: Oxford University Press., 1992.

Sihotang, AP dkk. "Reposisi Kedudukan Janda (Cerai Mati) Dalam Hukum Waris Adat Batak Dalam Perspektif Gender", journals.usm.ac.id, 2015.

Sihotang, Amri and Mahmuhtarom, HR. "Reposition of Widow's Position (Divorve Due To Death) In BatakCustomaryInheritance Law In Gender Perspective", Journal of Education and Social Sciences, Vol 6, Issue I, (2017). https://www.jesoc.com>2018/03

Tagwa dan Sadewo. "Kekerasan Simbolik pada Perempuan Janda di Kabupaten Sidoarjo", https://Jurnalmahasiswa.unesa.ac.id, 2016. 